\title{
Reproductive traits of the symbiotic pea crab Austinotheres angelicus (Crustacea, Pinnotheridae) living in Saccostrea palmula (Bivalvia, Ostreidae), Pacific coast of Costa Rica
}

\author{
Carolina Salas-Moya', Sebastián Mena', Ingo S. Wehrtmann ${ }^{1,2}$ \\ I Escuela de Biologia, Universidad de Costa Rica, 11501-2060 San José, Costa Rica 2 Unidad de Investigación \\ Pesquera y Acuicultura (UNIP) del Centro de Investigación en Ciencias del Mar y Limnología (CIMAR), \\ Universidad de Costa Rica, 11501-2060 San José, Costa Rica
}

Corresponding author: Carolina Salas-Moya (carosalasm@gmail.com)

Academic editor: R. T. Bauer | Received 5 May 2014 | Accepted 14 October 2014 | Published 25 November 2014

http://zoobank.org/949E6C2C-91E8-4F62-9919-0BFBAF82243B

Citation: Salas-Moya C, Mena S, Wehrtmann IS (2014) Reproductive traits of the symbiotic pea crab Austinotheres angelicus (Crustacea, Pinnotheridae) living in Saccostrea palmula (Bivalvia, Ostreidae), Pacific coast of Costa Rica. In: Wehrtmann IS, Bauer RT (Eds) Proceedings of the Summer Meeting of the Crustacean Society and the Latin American Association of Carcinology, Costa Rica, July 2013. ZooKeys 457: 239-252. doi: 10.3897/zookeys.457.7851

\begin{abstract}
Pea crabs of the family Pinnotheridae exhibit a symbiotic life style and live associated with a variety of different marine organisms, especially bivalves. Despite the fact that pea crabs can cause serious problems in bivalve aquaculture, the available information about the ecology of these crabs from Central America is extremely limited. Therefore, the present study aimed to describe different reproductive features of the pinnotherid crab Austinotheres angelicus associated with the oyster Saccostrea palmula in the Golfo de Nicoya, Pacific coast of Costa Rica. Monthly sampling was conducted from April to December 2012. Average carapace width $(\mathrm{CW})$ of the 47 analyzed ovigerous females was $7.62 \mathrm{~mm}$. The species produced on average $2677 \pm 1754$ recently -extruded embryos with an average volume of $0.020 \pm 0.003 \mathrm{~mm}^{3}$; embryo volume increased during embryogenesis by $21 \%$, but did not vary significantly between developmental stages. Brood mass volume varied greatly (between 11.7 and $236.7 \mathrm{~mm}^{3}$ ), and increased significantly with female CW. Females invested on average 76.7\% (minimum: 21.7\%; maximum: 162.8\%) of their body weight in brood production, which confirms a substantially higher energy allocation for embryo production in pinnotherid crabs compared to free-living decapods.
\end{abstract}

\section{Keywords}

Central America, fecundity, reproductive output, symbiosis

Copyright Carolina Salas-Moya et al. This is an open access article distributed under the terms of the Creative Commons Attribution License (CC BY 4.0), which permits unrestricted use, distribution, and reproduction in any medium, provided the original author and source are credited. 


\section{Introduction}

Symbiotic relationships in marine organisms are a well-documented phenomenon (Roughgarden 1975, Dos Santos-Alves and Pezzuto 1998, Boltańa and Thiel 2001, Thiel and Baeza 2001, Sotka 2005, Baeza 2007, Glynn 2013). The evolution of these symbiotic associations is shaped by cost and benefit aspects for both partners (Roughgarden 1975, Baeza 2007), but the role of ecological features responsible for the evolution of this lifestyle remains unclear (Baeza 2007). According to different studies (Baeza 2007, Ory et al. 2013), predation pressure is one of the principal forces driving the evolution of symbiotic associations in decapods. Small marine decapods commonly live associated with anemones, echinoderms and a variety of other invertebrates, which may serve as refuge from predation, food source or mating site (Criales 1984, Bauer 2004, Wirtz et al. 2009, Ory et al. 2013). However, studies on symbiotic decapods are still scarce, especially in those cases where environmental conditions hamper direct observations (Baeza 1999).

The Pinnotheridae is a highly diverse family, currently with 52 genera and more than 300 described species (Ng et al. 2008, De Grave et al. 2009, Palacios-Thiel et al. 2009). Members of this family are known to exhibit symbiotic relationships with numerous other invertebrates, including mollusks, polychaetes, echinoderms, brachiopods, and other decapods (Manning and Morton 1987, Feldmann et al. 1996, Baeza 1999, Lardies and Castilla 2001, McDermott 2006, Peiró and Mantelatto 2011, Trottier et al. 2012). The type of symbiotic relationships ranges from parasitism to commensalism, and pinnotherids live in a facultative and/or obligate association with their hosts (Silas and Alagarswani 1965, Schmitt et al. 1973, Stevens 1990, Hamel et al. 1999). Detailed information about many aspects of the association between pinnotherid crabs and their host remain to be studied (McDermott 2006, Peiró et al. 2011). Several studies addressed different reproductive aspects of these symbiotic crabs, including the morphology of the reproductive system (Becker et al. 2011, 2012, 2013), mating system (Dos Santos-Alves and Pezzuto 1998, Baeza 1999, Peiró et al. 2013), intraspecific latitudinal effects on different reproductive attributes (Lardies and Castilla 2001), as well as fecundity (Báez and Martínez 1976, Hines 1992, Cabrera Peña et al. 2001, Lardies and Castilla 2001). Our knowledge about energy allocation in embryo production of pinnotherid crabs is scarce; however, results obtained from several species of pea crabs clearly demonstrated that brood masses of these crabs are extraordinarily large in relation to female body size when compared to free-living decapods (Hines 1992, Lardies and Castilla 2001). This high investment in brood production is related to two unique features of the pea crabs (Hines 1992): (1) their ovaries cover not only the cephalothorax, but extend into the abdomen; (2) the exoskeleton of females is not well calcified, which allows that the body is distensible during yolk accumulation.

The pinnotherid crab Austinotheres angelicus Lockington, 1877 (Fig. 1) is distributed along the Pacific coast from the Gulf of California, Mexico, to Colombia, and lives in association with oysters (Campos 2002). Life history aspects of this species are virtually unknown, and therefore, the present study aimed to describe fecundity, embryo 


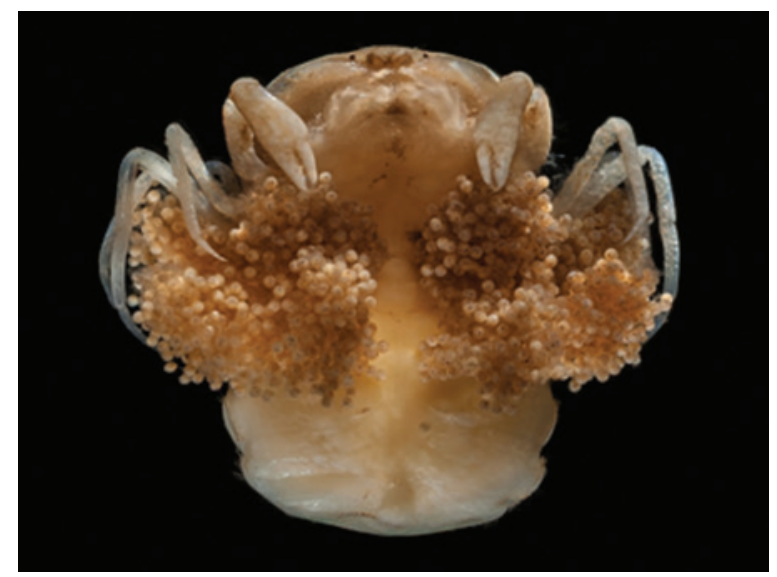

Figure I. Ovigerous female of Austinotheres angelicus from the Golfo de Nicoya, Pacific coast of Costa Rica.

volume, and reproductive output of $A$. angelicus living in the oyster Saccostrea palmula (Carpenter, 1857) in the Golfo de Nicoya, Pacific coast of Costa Rica. The results of this study will broaden our knowledge of the evolution of reproductive strategies in decapods adapted to live in association with other marine invertebrates.

\section{Methods}

\section{Field work}

The study site was Punta Morales, Golfo de Nicoya (Fig. 2), located at the Pacific coast of Costa Rica. The location is a sandy beach with a rocky intertidal zone, surrounded by mud flats and mangrove swamps (Rojas and Vargas 2008). Monthly sampling was carried out between April and December 2012; collections were conducted during diurnal low tides. During each sampling, 30 oysters (S. palmula) were collected, preserved in ethanol $(70 \%)$, and transported to the laboratory of the Unidad de Investigación Pesquera y Acuicultura (UNIP) of the Centro de Investigación en Ciencias del Mar y Limnología (CIMAR), Universidad de Costa Rica, in San José. Voucher specimens of A. angelicus were deposited in the collections of the Museo de Zoología, Universidad de Costa Rica (MZUCR 3281-01, 3282-01, 3283-01, 3284-01, 3285-01, 3286-01, 3287-01, 3288-01, 3289-01).

\section{Laboratory analyses}

Morphometric measurements of oysters (height, length, and thickness) were obtained with a digital caliper $( \pm 0.01 \mathrm{~mm})$; the three morphometric variables were multiplied in order to calculate the approximate volume of each oyster (OV). Each individual of 


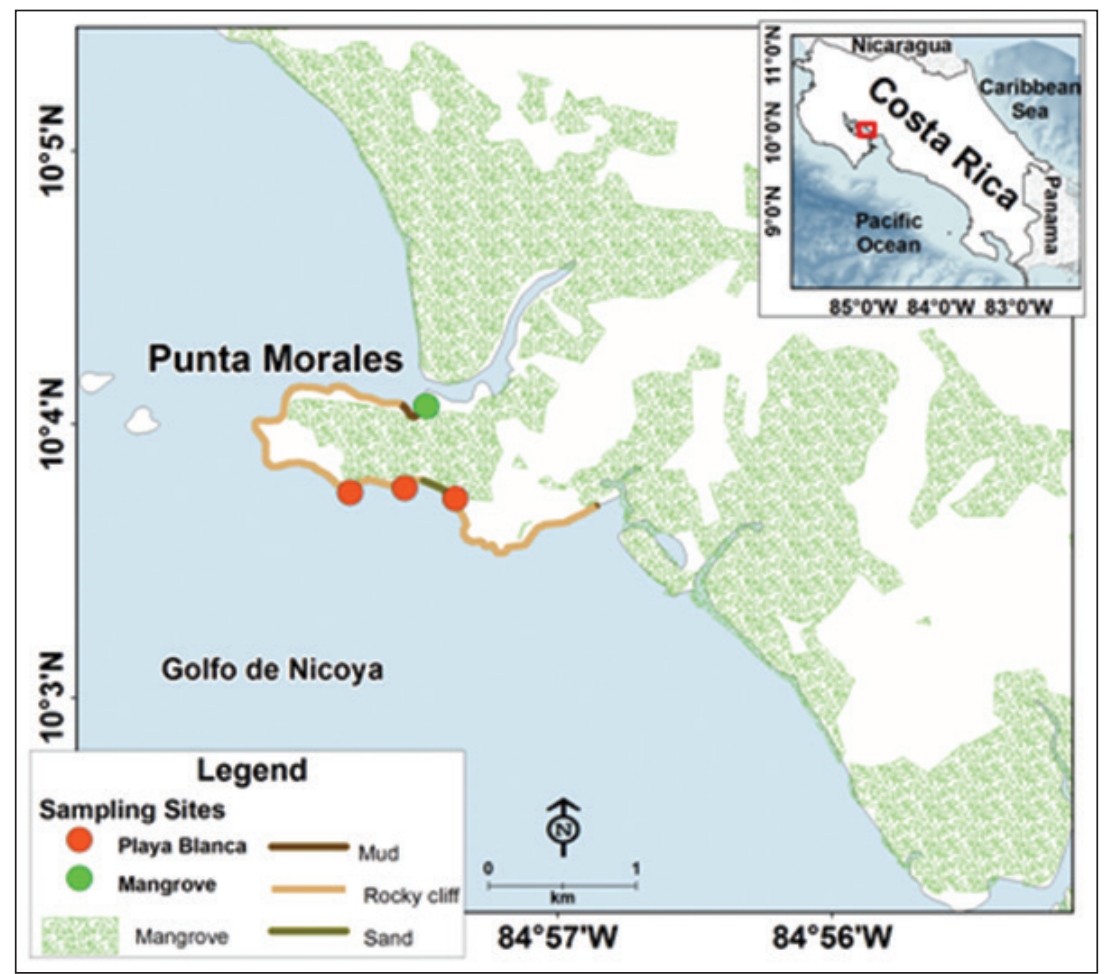

Figure 2. Sampling sites in Punta Morales, Golfo de Nicoya, Pacific coast of Costa Rica.

S. palmula was carefully opened and inspected for associated pea crabs. The carapace length (CL: distance between distal part of the eye socket to the posterior margin of the carapace), carapace width (CW: distance between lateral margins of the carapace), abdomen length (AL: distance between posterior margin of the carapace to the distal part of the abdomen) and abdomen width (AW: distance between lateral margins of the abdomen) were measured with the aid of a Leica MS5 stereoscopic microscope equipped with a calibrated ocular micrometer.

The entire brood mass was detached from ovigerous females $(n=47)$, evenly distributed on a Petri dish, and photographed (Benq GH650). These images were analyzed subsequently with the program Image ${ }^{\oplus}$ versión 1.46 r to count the total number of embryos carried by each ovigerous female. Embryos were staged according to the following criteria (Wehrtmann 1990): Stage I, uniform yolk, no eye pigments observed; Stage II, eye pigments scarcely visible; Stage III, embryo with eye pigments clearly visible and fully developed. Embryo volume (EV) was estimated using the equation (1) proposed by Corey and Reid (1991):

$$
E V=\left(\frac{b}{2}\right)^{2} \times a \times \pi
$$


where $a$ is the major diameter, and $b$ is the perpendicular diameter. A total of 15 embryos were measured from each female, and the average embryo volume was multiplied by the total number of embryos per female to calculate brood mass volume.

Females and their separated brood masses were dried at $60^{\circ} \mathrm{C}$ for 48 hours, and dry weights were measured to calculate the reproductive output (RO): dry weight of total brood mass per female / dry weight of females without brood mass (Hines 1988). The $\mathrm{RO}$ was estimated exclusively for females carrying recently extruded embryos (Stage I).

\section{Data analyses}

The Kruskal-Wallis test was applied to detect possible differences in both brood numbers between the three embryonic stages, and embryo volume during embryogenesis. Simple linear regressions and the Pearson correlation coefficient were calculated to determine the relation between both host morphometry (OV: volume of the oyster) and $\mathrm{CW}$ of $A$. angelicus (considering exclusively females with recently -produced embryos), fecundity (exclusively embryos in Stage I) and the following morphometric variables of the female: CW, CL, AW, and AL; and finally brood mass volume and CW of ovigerous females. All statistical analyses were carried out with $\mathrm{JMP}^{\oplus}$ version 7.0.

\section{Results}

The CW of the ovigerous female crabs averaged $7.62 \mathrm{~mm}$, and ranged in size from 5.02 to $14.25 \mathrm{~mm}$ (Table 1). Mean fecundity was 2677 in Stage I and 4890 embryos in females with brood masses in Stage III (Table 1); however, mean embryo number did not vary significantly between developmental stages $\left(\chi^{2}=2.57 ; \mathrm{gl}=2 ; \mathrm{p}=0.28\right)$. The $\mathrm{CW}$ of $A$. angelicus was significantly influenced by the volume of its host, $S$. palmula $(\mathrm{t}=3.74 ; \mathrm{n}=38 ; \mathrm{p}=0.0006)$ (Fig. 3). Fecundity was positively related with all morphometric variables of $A$. angelicus (Table 2); the variable, which best explained the number of embryos was CW (Fig. 4). Brood mass volume varied between 11.70 $\mathrm{mm}^{3}(7.25 \mathrm{~mm} \mathrm{CW})$ and $236.70 \mathrm{~mm}^{3}(14.25 \mathrm{~mm} \mathrm{CW})$, and increased significantly with female CW $(\mathrm{t}=5.09 ; \mathrm{n}=47 ; \mathrm{p}<0.001)$ (Fig. 4). Recently produced embryos

Table I. Fecundity, embryo volume during embryogenesis (Stage I-III) and carapace width of corresponding ovigerous females of Austinotheres angelicus ( $\mathrm{n}=47$ ), Golfo de Nicoya, Pacific coast of Costa Rica.

\begin{tabular}{|c|c|c|c|c|c|c|c|c|c|c|c|c|c|}
\hline \multirow{2}{*}{ Stage } & \multirow[b]{2}{*}{$\mathrm{N}$} & \multicolumn{4}{|c|}{ Fecundity } & \multicolumn{4}{|c|}{ Embryo volume $\left(\mathrm{mm}^{3}\right)$} & \multicolumn{4}{|c|}{ Carapace width (mm) } \\
\hline & & Av & SD & Min & Max & Av & SD & Min & Max & Av & SD & Min & Max \\
\hline I & 35 & & 1764 & & 7527 & 0.020 & & 0.013 & 0.027 & 7.60 & 1.18 & 5.02 & 10.87 \\
\hline II & 6 & 3029 & 2599 & 955 & 7900 & 0.023 & 0.005 & 0.017 & 0.031 & 7.27 & 1.21 & 5.70 & 9.00 \\
\hline III & 6 & 4890 & 3176 & 830 & 8509 & 0.024 & 0.005 & 0.017 & 0.031 & 8.10 & 3.10 & 6.07 & 14.25 \\
\hline
\end{tabular}


Table 2. Relation between morphometric features (CW, CL, AW, and AL) and fecundity in Austinotheres angelicus $(\mathrm{n}=47)$ in the Golfo de Nicoya, Pacific coast of Costa Rica.

\begin{tabular}{c|c|c|c|c}
\hline & CW & CL & AW & AL \\
\hline $\mathbf{R}^{2}$ & 0.33 & 0.09 & 0.29 & 0.29 \\
\hline $\mathbf{T}$ & 4.69 & 2.13 & 4.27 & 4.25 \\
\hline $\mathbf{P}$ & $<0.001$ & 0.04 & 0.001 & $<0.001$ \\
\hline
\end{tabular}

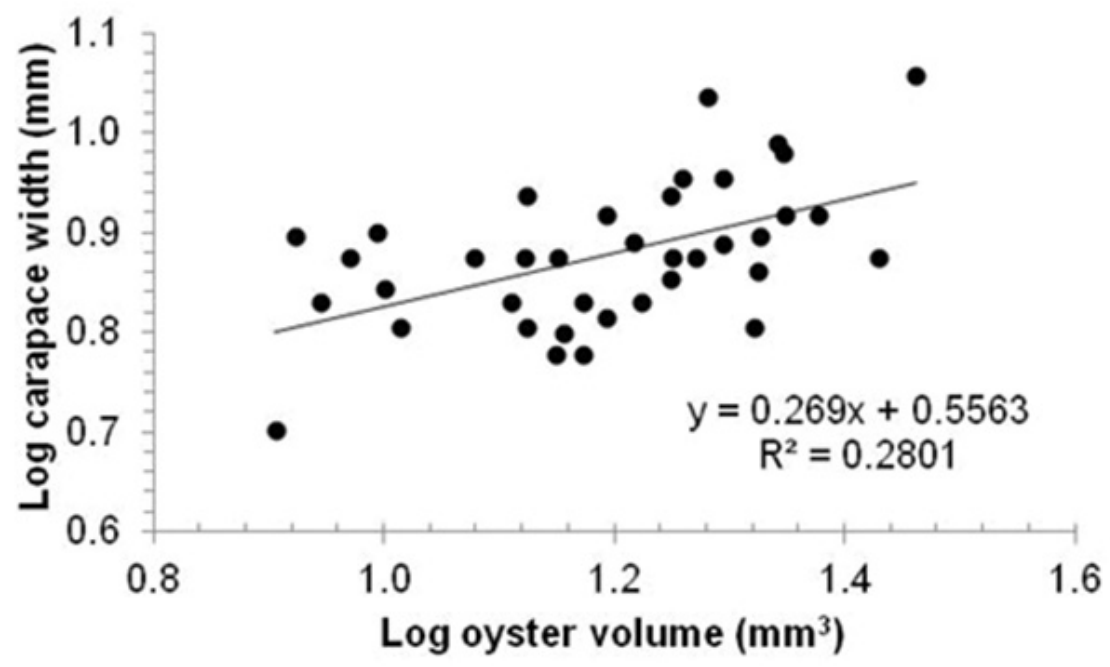

Figure 3. Relation between oyster volume (Saccostrea palmula) and carapace width of ovigerous females of Austinotheres angelicus ( $\mathrm{n}=38$; exclusively females with recently produced embryos) in the Golfo de Nicoya, Pacific coast of Costa Rica.

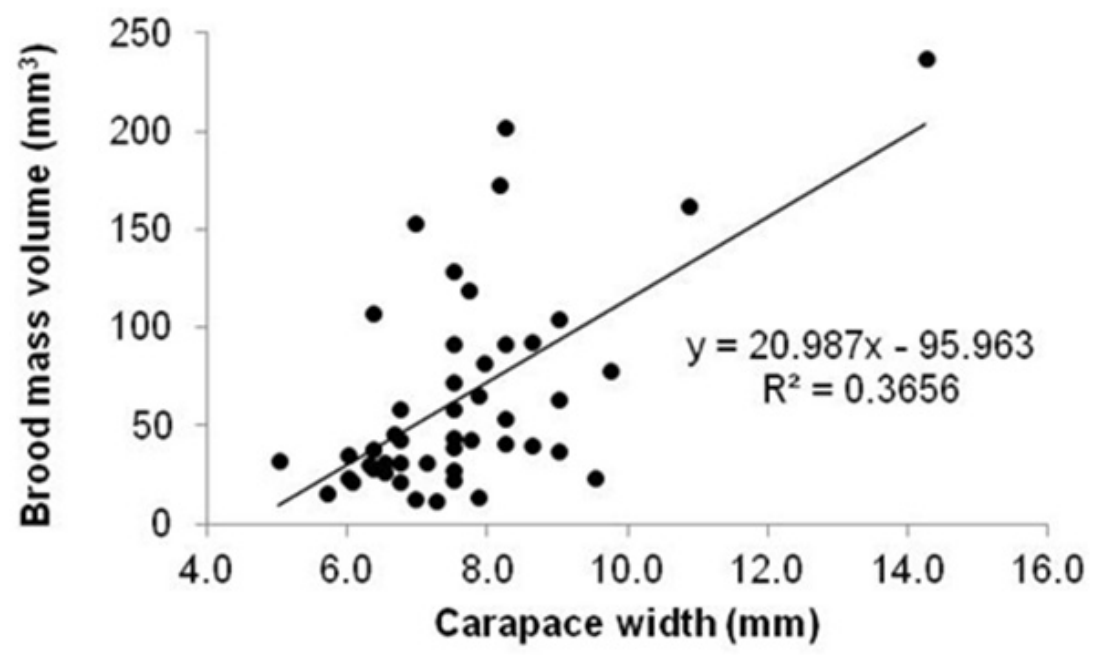

Figure 4. Relation between brood mass volume and carapace width of ovigerous females of Austinotheres angelicus $(\mathrm{n}=47)$ in the Golfo de Nicoya, Pacific coast of Costa Rica. 
(Stage I) had an average volume of $0.020 \mathrm{~mm}^{3}$, while those close to hatching (Stage III) measured $0.024 \mathrm{~mm}^{3}$ (Table 1); embryo volume increased during the embryogenesis by $21 \%$, but did not vary significantly between stages $\left(\chi^{2}=4.51 ; \mathrm{gl}=2 ; \mathrm{p}=0.10\right)$. The mean $\mathrm{RO}$ was $76.7 \pm 28.90 \%$, and values fluctuated between 21.7 and $162.8 \%$.

\section{Discussion}

This is the first published report on reproductive aspects of $A$. angelicus. Cabrera Peña et al. (2001) studied the size composition and fecundity of Juxtafabia muliniarum (Rathbun, 1918) in the Pacific of Costa Rica; however, according to Campos and Vargas-Castillo (2014) they confused the species with A. angelicus. Regarding reproductive traits, Cabrera Peña et al. (2001) provided only average embryo numbers and stated that ovigerous females of this pea crab species were present throughout the study period (May 1998 to May 1999).

\section{Fecundity}

Brood size increases with female body size have been well documented for pinnotherids (Hines 1992); not surprisingly, this study has found that small-sized species such as $A$. angelicus produce less offspring than substantially larger species (Table 3 ). The only other published data about reproductive features of $A$. angelicus (Cabrera Peña et al. 2001; reported as J. muliniarum) indicate a slightly lower average fecundity than obtained in the present study (Table 3). This difference is probably related to the fact that our material contained larger females (as $\mathrm{CW}$ ) as compared to those specimens analyzed by Cabrera Peña et al. (2001).

\section{Brood loss}

Brood loss is a well described phenomenon in decapods (for review: Kuris 1991). Our results did not reveal any embryo loss during the embryogenesis in A. angelicus; in fact, average embryo number in Stage I was higher than in Stage III (Table 1). This surprising result is explained by the fact that in our study specimens carrying embryos in Stage III were considerably larger than those with recently extruded embryos (Table 1). Lardies and Castilla (2001) hypothesized that the internal habitat of the host as well as the immobility of the commensal may effect reduction of embryo loss when they found low brood mortality rates in Pinnaxodes chilensis H. Milne Edwards, 1837, living as a commensal on a sea urchin. Our data seem to corroborate this hypothesis. However, additional studies with similar-sized females of $A$. angelicus carrying embryos in different developmental stages are necessary to answer the question whether decapods protected by its host show less or no brood mortality during embryogenesis. 


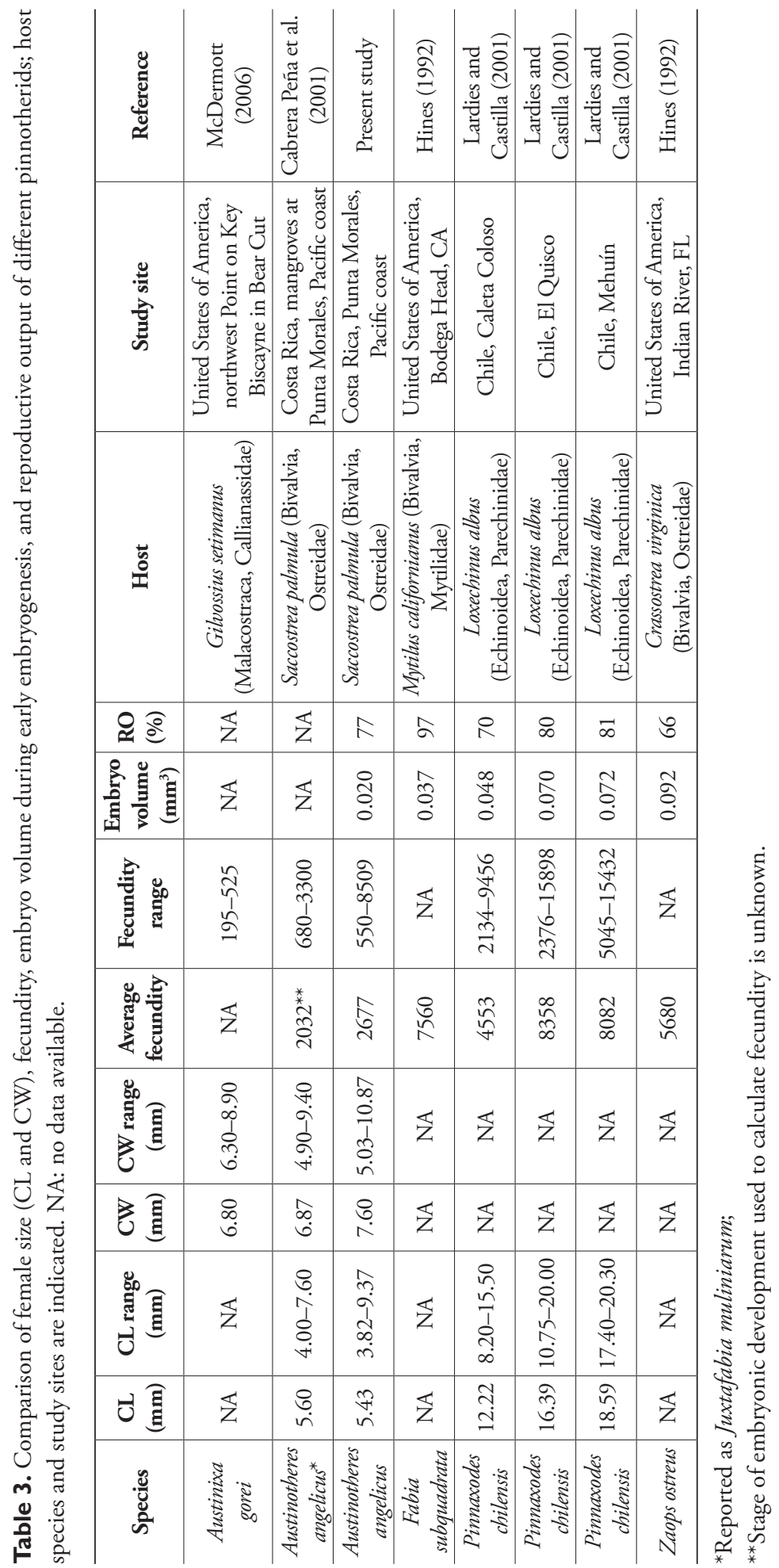




\section{Embryo volume}

The embryo volume of $A$. angelicus increased during the incubation period by $21 \%$. This increase is relatively low when compared to other marine decapods living in association with other invertebrates: Synalpheus yano (Ríos \& Duffy, 2007) in the sponge Lissodendoryx colombiensis Zea \& van Soest, 1986; 118\% (Hernáez et al. 2010); and, Pinnaxodes chilensis (H. Milne Edwards, 1837) in the sea urchin Loxechinus albus (Molina, 1782): ranging from 58 to 77\% (Lardies and Castilla 2001). Lardies and Wehrtmann (1996) suggested that increased water uptake during embryogenesis might serve as a buffer against environmental changes outside the embryo. Therefore, low embryo volume increase might suggest relatively stable conditions for embryo development of A. angelicus in its host.

Embryo size has been considered as an indicator for energy content provided by the female (McEdward and Coulter 1987). Compared to other pinnotherids (Table 3), A. angelicus produced relatively small embryos, and the embryo volume $\left(0.020 \mathrm{~mm}^{3}\right)$ is considerably smaller than the average value $\left(0.045 \mathrm{~mm}^{3}\right)$ calculated for 35 brachyuran crab species (Hines 1992). Therefore, it is concluded that females of $A$. angelicus allocate a relatively small amount of energy per embryo. However, this low maternal investment per offspring is compensated by a relatively large brood mass, which is reflected by extraordinary high $\mathrm{RO}$ values (up to $162.8 \%$ ). These findings corroborate results of previous studies with pea crabs (Hines 1992, Lardies and Castilla 2001), which revealed substantially higher reproductive investment compared to other free-living decapod species. According to Hines (1992), the following features might explain the high RO values in pinnotherid crabs: (1) apparently in contrast to other decapods, ovaries of pinnotherids can extend from the cephalothorax into the abdomen, thus creating additional space for egg accumulation; (2) the protected habitat allows a reduced calcification of the exoskeleton, which in turn diminishes female body weight and makes the body more flexible, allowing to distend during egg accumulation. The high $\mathrm{RO}$ values of pinnotherid crabs are an adaptation to its symbiotic life style (Hines 1992). Our results regarding $A$. angelicus provide further evidence that pinnotherids can produce proportionately much larger broods than free-living crabs.

\section{Relation between host size and Austinotheres angelicus}

The size of $A$. angelicus increased significantly with the volume of its host, $S$. palmula. This finding concurs with results reported by Sun et al. (2006) who found that CWs of the pea crab Pinnotheres sinenis Shen, 1932 increased with the weight of both the shell and the soft tissue of its host Mytilus galloprovincialis. Also, Atkins (1926) found the largest individuals of Pinnotheres pisum (Linnaeus, 1767) in large-sized specimens of its host mussel, Mytilus edulis. 


\section{Conclusions}

Representatives of the family Pinnotheridae have evolved a series of adaptations to cope with their symbiotic life style (Hines 1992; Peiró and Mantelatto 2011), which makes them an interesting model to study the evolution of associations between decapods and other invertebrates. Here we present results on reproductive features of $A$. angelicus, which lives in association with oysters. Since the host plays a fundamental role in the life cycle of the pea crab, it seems necessary to get a better understanding of the interactions between population dynamics of the host and adaptive responses of the symbiotic pea crab. Hernández et al. (2012) assumed that small host populations induce pea crabs to adopt a solitary life style, and predicted that stable dwellings stimulate extended parental care. Moreover, the larval phase and recruitment processes are unknown in $A$. angelicus, and it has been speculated that pinnotherid larvae suffer higher mortality rates while searching for the specialized recruitment place (different types of hosts) than free-living species (Lardies and Castilla 2001). Finally, A. angelicus has been reported as symbiont from different hosts (Campos 2002), which raises the question if populations of this pea crab develop different life cycle adaptations in different hosts.

\section{Acknowledgements}

We would like to acknowledge the logistic support provided by the Estación de Ciencias Marino Costeras (ECMAR). A special thanks goes to Raymond T. Bauer for his support and suggestions. Rita Vargas and Ernesto Campos helped us with the identification of Austinotheres angelicus, Julian Schneider took the photographs of the species, Fiorella Vásquez and Gustavo Arias assisted during some sampling trips; thanks goes to Juan José Alvarado for his interest in this study, and Raquel Romero Chaves prepared the map with the sampling locations; to all of them: muchas gracias!

\section{References}

Atkins D (1926) The moulting stages of the pea-crab (Pinnotheres pisum). Journal of Marine Biology Association 14: 475-493. doi: 10.1017/S0025315400007955

Báez RP, Martínez FC (1976) Desove y fecundidad de Pinnaxodes chilensis (H. Milne Edwards, 1837) (Crustacea, Decapoda, Brachyura, Pinnotheridae). Anales del Museo de Historia Natural de Valparaíso 9: 45-60.

Baeza JA (1999) Indicadores de monogamia en el cangrejo comensal Pinnixa transversalis (Milne Edwards \& Lucas) (Decapoda: Brachyura: Pinnotheridae): distribución poblacional, asociación macho-hembra y dimorfismo sexual. Revista de Biología Marina y Oceanografía 34: 303-313. 
Baeza JA (2007) The origins of symbiosis as a lifestyle in marine crabs (genus Petrolisthes) from the eastern Pacific: Does interspecific competition play a role? Revista de Biología Marina y Oceanografía 42: 7-21. doi: 10.4067/S0718-19572007000100002

Bauer RT (2004) Symbioses. In: Bauer RT (Ed.) Remarkable Shrimps: Adaptations and Natural History of the Carideans. Oklahoma University Press, Norman, 179-203.

Becker C, Brandis D, Storch V (2011) Morphology of the female reproductive system of European pea crabs (Crustacea, Decapoda, Brachyura, Pinnotheridae). Journal of Morphology 272: 12-26. doi: 10.1002/jmor.10884

Becker C, Klaus S, Tudge CC (2013) Male internal reproductive structures of European pea crabs (Crustacea, Decapoda, Brachyura, Pinnotheridae): Vas deferens morphology and spermatozoal ultrastructure. Journal of Morphology 274: 1312-1322. doi: 10.1002/ jmor.20184

Becker C, Türkay M, Brandis D (2012) The male copulatory system of European pea crabs (Crustacea, Brachyura, Pinnotheridae). Journal of Morphology 273: 1306-1318. doi: 10.1002/jmor.20065

Boltańa S, Thiel M (2001) Associations between two species of snapping shrimp, Alpheus inca and Alpheopsis chilensis (Decapoda: Caridea: Alpheidae). Journal of the Marine Biological Associations of the United Kingdom 81: 633-638.

Cabrera Peña J, Protti-Quesada M, Urriola-Hernández M, Sáenz-Vargas O, Alfaro-Hidalgo R (2001) Tallas y fecundidad de Juxtafabia muliniarum (Brachyura: Pinnotheridae) asociado con Saccostrea palmula (Bivalvia: Ostreidae), Costa Rica. Revista de Biología Tropical 49: 889-894.

Campos E (2002) Two new genera of pinnotherid crabs from the Tropical Eastern Pacific (Decapoda: Brachyura: Pinnotheridae). Journal of Crustacean Biology 22: 328-336. doi: $10.1163 / 20021975-99990239$

Campos E, Vargas-Castillo R (2014) The identity of the symbiotic crab Juxtafabia muliniarum sensu Cabrera-Peña et al. (2001) (Crustacea, Brachyura, Pinnotheridae). Latin American Journal of Aquatic Research 42: 598-603.

Corey S, Reid DM (1991) Comparative fecundity of decapod crustaceans: The fecundity of thirty-three species of nine families of caridean shrimp. Crustaceana 60: 270-294. doi: $10.1163 / 156854091 X 00056$

Criales MM (1984) Shrimps associated with coelenterates, echinoderms, and molluscs in the Santa Marta region, Colombia. Journal of Crustacean Biology 4: 307-317. doi: $10.2307 / 1548028$

De Grave S, Pentcheff ND, Ahyong ST, Chan TY, Crandall KA, Dworschak PC, Felder DL, Feldmann RM, Fransen CHJM, Goulding LYD, Lemaitre R, Low MEY, Martin JW, Ng PKL, Schweitzer CE, Tan SH, Tshudy D, Wetzer R (2009) A classification of living and fossil genera of decapod crustaceans. Raffles Bulletin of Zoology Supplement 21: 1-109.

Dos Santos-Alves E, Pezzuto PR (1998) Population dynamics of Pinnixa patagoniensis Rathbun 1918 (Brachyura: Pinnotheridae) a symbiotic crab of Sergio mirim (Thalassinidea: Callianassidae) in Cassino Beach, southern Brazil. Marine Ecology 19: 37-51. doi: 10.1111/ j.1439-0485.1998.tb00452.x 
Feldmann RM, Mackinnon DI, Endo K, Chirino-Galvez L (1996) Pinnotheres laquei Sakai (Decapoda: Pinnotheridae), a tiny crab commensal within the brachiopod Laqueus rubellus (Sowerby) (Terebratulida: Laqueidae). Journal of Paleontology 70: 303-311.

Glynn PW (2013) Fine-scale interspecific interactions of coral reef: Functional roles of small and cryptic metazoans. Smithsonian Contributions to Marine Science 39: 229-248.

Hamel JF, Ng PKL, Mercier A (1999) Life cycle of the pea crab Pinnotheres halingi sp. nov., an obligate symbiont of the sea cucumber Holothuria scabra Jaeger. Ophelia 50: 149-175. doi: 10.1080/00785326.1999.10409393

Hernáez P, Martínez-Guerrero B, Anker A, Wehrtmann IS (2010) Fecundity and effects of bopyrid infestation on egg production in the Caribbean sponge-dwelling snapping shrimp Synalpheus yano (Decapoda, Alpheidae). Journal of the Marine Biological Association of the United Kingdom 90: 691-698. doi: 10.1017/S0025315409991093

Hernández JE, Bolaños JA, Palazón JL, Hernández G, Lira C, Baeza JA (2012) The enigmatic life history of the symbiotic crab Tunicotheres moseri (Crustacea, Brachyura, Pinnotheridae): Implications for its mating system and population structure. Biological Bulletin 223: $278-290$.

Hines AH (1988) Fecundity and reproductive output in two species of deep-sea crabs, Geryon fenneri and G. quinquedens (Decapoda: Brachyura). Journal of Crustacean Biology 8: 557-562. doi: 10.2307/1548692

Hines AH (1992) Constraint on reproductive output in brachyuran crabs: Pinnotherids test the rule. American Zoology 35: 503-511.

Kuris AM (1991) A review of patterns and causes of crustacean brood mortality. In: Wenner A, Kuris AM (Eds) Crustacean Egg Production. A. A. Balkema, Rotterdam. Crustacean Issues 7: 117-141.

Lardies MA, Castilla JC (2001) Latitudinal variation in the reproductive biology of the commensal crab Pinnaxodes chilensis (Decapoda: Pinnotheridae) along the Chilean coast. Marine Biology 139: 1125-1133. doi: 10.1007/s002270100661

Lardies MA, Wehrtmann IS (1996) Aspects of the reproductive biology of Petrolisthes laevigatus (Guérin, 1835) (Decapoda, Anomura, Porcellanidae). Part I: reproductive output and chemical composition of eggs during embryonic development. Archives of Fishery and Marine Research 43: 121-135.

Manning RB, Morton B (1987) Pinnotherids (Crustacea: Decapoda) and leptonaceans (Mollusca: Bivalvia) associated with sipunculan worms in Hong Kong. Proceedings of the Biological Society of Washington 100: 543-551.

McDermott JJ (2006) The biology of Austinixa gorei (Manning \& Felder, 1989) (Decapoda, Brachyura, Pinnotheridae) symbiotic in the burrows of intertidal ghost shrimp (Decapoda, Thalassinidea, Callianassidae) in Miami, Florida. Crustaceana 79: 345-361. doi: $10.1163 / 156854006776759608$

McEdward LR, Coulter LK (1987) Egg volume and energetic content are not correlated among sibling offspring of starfish: implications for life-history theory. Evolution 41: 914-917. doi: 10.2307/2408900

Ng PKL, Guinot D, Davie PJF (2008) Systema Brachyurorum: Part 1. An annotated checklist of extant brachyuran crabs of the world. Raffles Bulletin of Zoology 17: 1-286. 
Ory N, Dudgeon C, Thiel M (2013) Host-use patterns and factors influencing the choice between anemone and urchin hosts by a caridean shrimp. Journal of Experimental Marine Biology and Ecology 449: 85-92. doi: 10.1016/j.jembe.2013.09.002

Palacios-Thiel E, Cuesta JA, Campos E, Felder DL (2009) Molecular genetic re-examination of subfamilies and polyphyly in the Family Pinnotheridae (Crustacea: Decapoda). In: Martin JW, Crandall KA, Felder DL (Eds) Decapod Crustacean Phylogenetics. Taylor \& Francis/ CRC Press, Florida. Crustacean Issues 18: 423-442.

Peiró DF, Mantelatto FL (2011) Population dynamics of the pea crab Austinixa aidae (Brachyura, Pinnotheridae): A symbiotic of the ghost shrimp Callichirus major (Thalassinidea, Callianassidae) from the southwestern Atlantic. Iheringia 101: 5-14.

Peiró DF, Baeza JA, Mantelatto FL (2013) Host-use pattern and sexual dimorphism reveals the mating system of the symbiotic pea crab Austinixa aidae (Crustacea: Brachyura: Pinnotheridae). Journal of the Marine Biological Association of the United Kingdom 93: 715-723. doi: 10.1017/S0025315412000720

Peiró DF, Pezzuto PR, Mantelatto FL (2011) Relative growth and sexual dimorphism of Austinixa aidae (Brachyura: Pinnotheridae): a symbiont of the ghost shrimp Callichirus major from the southwestern Atlantic. Latin American Journal of Aquatic Research 39: 261-270. doi: 10.3856/vol39-issue2-fulltext-7

Ríos R, Duffy E (2007) A review of the sponge-dwelling snapping shrimp from Carrie Bow Cay, Belize, with description of Zuzalpheus, new genus, and six new species (Crustacea: Decapoda: Alpheidae). Zootaxa 1602: 1-89.

Rojas RE, Vargas JA (2008) Abundancia, biomasa y relaciones sedimentarias de Americonuphis reesei (Polychaeta: Onuphidae) en el Golfo de Nicoya, Costa Rica. Revista de Biología Tropical 56: 59-82.

Roughgarden J (1975) Evolution of marine symbiosis - A simple cost-benefit model. Ecology 56: 1201-1208. doi: 10.2307/1936160

Schmitt WL, McCain JC, Davidson E (1973) Decapoda I. Brachyura I. Fam. Pinnotheridae. In: Gruner HE, Holthuis LB (Eds) Crustaceorum Catalogus. Dr. W. Junk, Den Haag 3: 1-160.

Silas E, Alagarswami K (1965) On an instance by parasitisation by the pea-crab (Pinnotheres sp.) on the backwater clam [Meretrix casta (Chemnitz)] from India with a review of the work on the systematics, ecology, biology and ethology of pea crabs of the genus Pinnotheres Latreille. Marine Biological Association of India 2: 1162-1228.

Sotka EE (2005) Local adaptation in host use among marine invertebrates. Ecology Letters 8: 448-459. doi: 10.1111/j.1461-0248.2004.00719.x

Stevens PM (1990) Specificity of host recognition of individuals from different host races of symbiotic pea crabs (Decapoda: Pinnotheridae). Journal of Experimental Marine Biology and Ecology 143: 193-207. doi: 10.1016/0022-0981(90)90070-S

Sun W, Sun S, Yuqi W, Baowen Y, Weibo S (2006) The prevalence of the pea crab, Pinnotheres sinenis, and its impact of the condition of the cultured mussel, Mytilus galloprovincialis, in Jiaonan waters (Shandong Province, China). Aquaculture 253: 57-63. doi: 10.1016/j. aquaculture.2005.07.037

Thiel M, Baeza JA (2001) Factors affecting the social behaviour of crustaceans living symbiotically with other marine invertebrates: A modelling approach. Symbiosis 30: 163-190. 
Trottier O, Walker D, Jeffs AG (2012) Impact of the parasitic pea crab Pinnotheres novaezelandiae on aquacultured New Zealand green-lipped mussels, Perna canaliculus. Aquaculture 344-346: 23-28. doi: 10.1016/j.aquaculture.2012.02.031

Wehrtmann IS (1990) Distribution and reproduction of Ambidexter panamense and Palaemonetes schmitti, in Pacific Costa Rica (Crustacea: Decapoda). Revista de Biología Tropical 38: 327-329.

Wirtz P, de Melo G, de Grave S (2009) Symbioses of decapod crustaceans along the coast of Espírito Santo, Brazil. Marine Biodiversity Records 2: e162. doi: 10.1017/ S175526720999087X 